\title{
ONE-WAY THEORY: ON THE HISPANIC-ATLANTIC INTERSECTION OF POSTCOLONIALITY AND POSTNATIONALISM AND ITS GLOBALIZING EFFECTS
}

(C) Joseba Gabilondo

University of Florida

E-mail-gabilond@rll.ufl.ed

This article is a first elaboration of two different political and cultural problems I have encountered when mapping the globalization of Spain from my position as Basque Hispanist and theorist of North American film. I call the first one the "Antonio Banderas Effect" and the second the "Like Water for Chocolate Effect" (or as I will define it more precisely later on the "Like Blood for Chocolate Effect"). As epidermic and frivolous as these labels might sound, I think they compensate for the highly theoretical title of the article. They are intended as a subtitle to a lecture that begins with two "post-"s at the same time that they are meant to be a very material and irreducible reference to otherwiseslippery categories such as "postnational." These two problems or "effects" will also help us locate the main issue that this article addresses: the one-directional flow of knowledge, and more specifically academic theoretical production, from the first world to the second and the third. In the case of Spanish academic production, ironically enough, the unidirectional character of knowledge is much more pronounced than in the Latin American, although both cases end in what Alberto Moreiras calls "historical Latin Americanism," and if we extend it to the Spanish case, "historical Hispanism" tout court. "Historical Hispanism" is a specific but telling case of the general problem of "area studies," one that requires what Joan Ramón Resina calls "Meta-Hispanism" (127-28) as corrective of its own positionality.

This article thus will concentrate on the Atlantic and global aspects of a putative Meta-Hispanism, so that if the resulting Meta-Hispanism has a political unconscious is one defined by the explicit insertion of these two new referents: global and Atlantic. The ultimate question is, of course, whether a Meta-Hispanism is possible in an Atlantic and global context. This article rather than affirming or denying such possibility, will underscore the political and cultural importance of thinking its impossibility. In other words, this article will defend that the importance and necessity of a Meta-Hispanism relies precisely in the awareness of its impossibility. From this awareness I will define another Hispanic space: the "Hispanic-Atlantic intersection of the postcolonial and the postnational." I will ultimately defend that this 
relocation has important consequences for a global understanding of both Latinamericanism and Hispanism.

\section{THE BANDERAS EFFECT}

Although the Banderas effect could be dated back to the European formation of "donjuanismo" in the late Enlightenment, it would be better situated chronologically by tracing it to 1994. That year, the largest percentage of rentals for Hollywood films came from the international rather than the domestic markets; that is, the main engine of American mass culture began to rely on foreign markets more than the domestic in order to secure its economic survival (Balio 60). That very same year, Spanish actor Antonio Banderas became popular in Hollywood. Although Banderas arrived to the United States in 1992 (The Mambo Kings), he made his "official" appearance in Hollywood in 1994, at the Oscar Awards ceremony. The year after the release of Philadelphia, he was introduced by Billy Crystal to the global viewership of the Oscars ceremony as "the sexiest man alive." That same year he made his second important film: Interview with the Vampire. After his North American debut and throughout the 90s, Banderas has set the standard for "sexualized" masculinity, as opposed to other forms of masculinity, such as the sadistic-Swartzenneger--or the suave--Hugh Grant. In short, the globalization of Hollywood coincides with the arrival of a new sexualized Hispanic masculinity to the recently inaugurated global arena of filmic mass culture.

What is most interesting about Banderas's arrival to the globalized scene of Hollywood is his geo-sexual and -political deployment. A heterosexual, Spanish actor, out of the movies of a gay Spanish director, Pedro Almodóvar, comes to represent Latin American, Latino, or gay characters in every mainstream film portraying such identities. For example, in Philadelphia, he plays Latino and gay at the same time. Thus, to the globalized filmic showcase of Hollywood, a Spanish heterosexual actor is most suitable to represent the Latino, Latin American, and gay reality. As a result, the old empire, Spain, once again gains prominence when representing a new "area" simultaneously defined as sexual and geopolitical. I would call this area the "good" and "don't ask, don't tell" "neighbor" area -- Latin America and homosexuality respectively--a "continuous neighborhood" to the geopolitical imagination of the US.

In order to see the relevance of the Banderas effect in the discussion of the Hispanic Atlantic and the unidirectional academic production, allow me to move on to a discussion of Anglo-American postcolonial theory. Spivak and Bhabha, theoreticians of Indian origin or descent, 
have come to define the state of postcoloniality in the USA, and only as a result of this new location, throughout the world as well. This is a discourse that, alongside cultural studies and queer theory, has revolutionized the Anglo-American academia of the 90s, although the process already began in the 80 s with feminism. In this respect, and although I do not concur in the final criticism of his work, I agree with Arif Dirlik when he states that "Postcolonialism begins when intellectuals of the Third World arrive to the academia of the first world" (xx), although I would add that they are intellectuals of the area of the Third World emerging from British imperialism . In order to grasp the historical importance of this organization of knowledge in the first world, it is important to note that the arrival of postcolonial theory, as well as cultural and queer studies, coincides with the decline of the hegemony of poststructuralism and, thus, French and European modernity and knowledge-production. Theory has moved from French to English, and thanks to postcolonialism, cultural studies, and queer theory, now has been made to coincide with the postcolonial axis of British imperialism--India-United Kingdom-USA--as well as its language: English. Consequently, French language and French poststructuralism move to a position similar to that occupied by German idealism and phenomenology--from Hegel to Husserl--for the former European continental organization of knowledge. Although I will come back to this issue, it is important to note that this shift has not been registered and accounted for in Spanish Peninsular academic knowledge production and thus the latter remains attached to the older European continental axis centered on France and Germany (and England as a peripheral extension to the continent). Of course, the exceptions are many and changes do occur fast, so I am aware that my geo-epistemological narrative could soon become dated or anachronistic. In this respect, the new wave of Hispanists located in the United States who, nevertheless, publish in Spanish, such as Angel Loueiro, Teresa Vilarós, or Isolina Ballesteros, constitutes an avant-garde in this shift of geo-epistemology.

At this point I would like to compare the Hispanic postcolonial axis of mass-culture discourse, organized around Banderas, and the British postcolonial axis of academic theoretical discourse, organized around Bhabha and Spivak (and to a lesser extent Said, Stuart Hall and cultural studies). Although such comparison might sound far-fetched at first, I believe it reflects the true spirit of what "global cultural studies" should be. Thus, if postcolonial knowledge is geopolitically situated, it appears that the postcolonial theorists of the bygone British empire serve as the new voices of cultural difference for the North American organization and deployment of the global power/knowledge order. In turn, it seems that the subject of a bygone empire, Banderas as Spanish, serves as the new representation and body of 
postcolonial cultural difference--the Latin American/Latino--for the same global order. In other words, in the case of postcolonial theory, a surrogate postcolonial Indian subject produces theory for the New American order of knowledge, whereas in the case of mass culture, a surrogate imperial Spanish subject produces a postcolonial representation for this same global organization of culture. In short, in the first case a postcolonial subject moves to the North American center of global culture and knowledge, whereas in the second case the same movement is effected by a postimperial subject. Although in both cases the mobilization responds to a surrogate postcolonia/imperialist maneuver, the object and relation represented are the opposite: the British and the Latin Americans.

Needless to say, in the two above cases, the North American discursive machine is vicariously living its own neocolonial and global order and psychodrama through two cases of European, modern imperialism--the British and the Spanish--but the geographies and subjects mobilized are the opposite. However, this mobilization coincides with the distribution of knowledge/power between first, second, and third worlds: the first world (the British) and its excolonies (third) produce knowledge whereas the second (the Spanish) and its ex-colonies (third) embody and represent knowledge. Thus one could conclude that if the British-Indian theorization of the global order for the US is "postcolonialism," then the Spanish-Latin American embodiment of the same order is "reversed postcolonialism:" it is the postimperial Spanish subject that reverses its position and becomes "a postcolonial representation" for the new North American deployment of global power/knowledge.

I will come back to the issue of "postcolonialism/reverse postcolonialism," but before I proceed, I would like to stress the geopolitical consequences of the Banderas effect for a globalized Spain. It follows from this effect that the main function of Spanish discourses and bodies, in the new globalized geoculture regulated by North America, is to represent Latino/Latin America, not the other way around--as in the case of postcolonial theory and British imperialism. Thus, if the Banderas effect is accepted in its geopolitical discursive implications, one must conclude that nowadays, for the global production and consumption of power/knowledge, both mass-oriented and academic, Spanish culture is a subset of Latin America, or to put it boldly: culturally speaking Spain is a region of Latin America. Spain is part of the Latin American area of studies.

On an academic level, I do not need to remind any North American "Hispanist" that, over the last twenty years or so, the American interest in Spain and more specifically Golden-Age studies has declined as the 
attention given to Latin America has risen, so that Peninsular studies have begun to undergo a "Latin American conversion." I believe that in order to articulate a global Meta-Hispanism, this effect must be accounted for as one of its central components.

As Elena Delgado points out, the introduction of North American academic knowledge still goes unnoticed in Spain among its intellectuals, and conversely, the narcissistic involvement with national identity, as derived from a primary European narcissism that excludes the periphery, still dictates the intellectual discourse in Spain. Delgado notes:

repasemos por un momento algunos de los títulos publicados en los últimos 5 años sobre la identidad cultural española o sobre la idea de nación en España: Si España cae....asalto nacionalista al Estado (César Alonso de los Rios, 1994) Nacionalismos: el laberinto de la hispanidad (Xabier Rubert de Ventós, 1994); España, una angustia nacional (Javier Tussell 1999); La novela de España: los intelectuales y el problema español (Javier Varela 1999); Tragedia y razón: Europa en el pensamiento español del siglo XX (José María Beneyto 1999). La ironía de estos títulos es que apuntan precisamente a lo que su contenido insite en negar: que la idea de la nación española o de su identidad cultural sea problemática, siendo significativo que la retórica utilizada para describir el "no-problema" enfatice los mismos términos que según Subirats habían sido desplazados: laberintos, tragedias, angustias y desvividurías. Naturalmente que podría arguirse, con razón, que todos estos libros lo que hacen es una revisión de unos fenómenos pasados; pero es significativo que todos ellos dediquen prácticamente la totalidad de sus páginas a analizar un problema supuestamente superado, para relegar a unas cuantas páginas finales "a modo de epílogo" a la realidad europea y "normalizada" de España.

Thus, my new cultural relocation of Spain within the North American global order already hints at a new Atlantic geography as well as a new postcolonial discourse, in which both the effects of European modernity and North American postmodernity are simultaneously registered.

Coming back to the issue of "postcolonialism/reverse postcolonialism," I would like to discuss the other main consequence of the Banderas effect in the global deployment of geopolitical knowledge/power in Anglo-American postcolonialism. If the Banderas effect points to a new type of "Hispanic postcolonial reason," in its reversed condition vis-à-vis the Anglo-American, then the Hispanic asserts its own difference, its own locus of enunciation to borrow Walter Mignolo's 
term, vis-à-vis both North America and Spain. At the same, time this putative "Hispanic postcolonial theory" relocates its Anglo-American counterpart in its specific situation, or to use Bhabha's term, location: Anglo-American postcolonial discourse no longer is "Postcolonial discourse" but "Anglo-American-postcolonial-discourse-of-NorthAmerican-postcoloniality." In this way, Hispanist and Latinamericanist postcolonial discourse breaks away from the epistemological flow of what I denominated one-way theory, which still reduces Latino / Latin America to a subset, a derived case, of Anglo-American postcolonial theory. At the same time, postcolonial discourses, in their new plurality, encounter each other in an Atlantic space while further complicating and, yet, rendering more precise, the location of postcolonial theories, Hispanic and Anglo-American alike.

\section{THE LIKE BLOOD FOR CHOCOLATE EFFECT}

One could look at the problem of "reverse postcolonialism" from the other end; that is, one could examine it under the "Like Water for Chocolate effect"--or as I will rename it later the "Like Blood for Chocolate effect."

In his essay on testimonio literature, John Beverley, among others, summarizes the state of Latin Americanist studies, and more specifically the production of theory over the last twenty years, as different discursive and political changes have occurred in Latin America. When he recaps the aftermath of the Chilean coup of 1973-as the socialist utopia opened up by the Cuban revolution fades away-he centers the changes in literary and discursive production around the shift from magic realism to testimonio:

Testimonio began as an adjunct to armed liberation struggle in Latin America and elsewhere in the Third World in the sixties. But its canonization was tied even more, perhaps, to the military, political, and economic force of counterrevolution in the years after 1973. It was the Real, the voice of the body in pain, of the disappeared, of the losers in the rush to marketize, that demystified the false utopian discourse of neoliberalism, its claims to have finally reconciled history and society. At the same time, testimonio relativized the more liberal or even progressive claim of the high-culture writers and artists of the book to speak for the majority of Latin Americans. It marked a new site of discursive authority, which challenged the authority of the "great 
writer" to establish the reality principle of Latin American culture and development. (281)

Ironically enough when most academics in North America were concerned with the political and epistemological implications of testimonio, as discourse and theory of politics, North America turned around and consumed a Latin American product that, in its hybridity, seems to condense both, magic realism and testimonio, in one single discourse. I am referring to the foreign film with the highest box-office returns in North American history: Like Water for Chocolate (1992). Even at the level of production, the literary "testimonio of a Mexican writer," her "true and real" literary production, was transcribed and put down on film for worldwide consumption by a director familiar with Hollywood. Alfonso Arau, the director of the film, was better known before for his representations of Mexicans in films such as The Wild Bunch. I am tempted to define this "filmic transcription" the visualization and massification of testimonio via magic realism; "two discourses for the price of one."

As a result, Like Water for Chocolate was consumed as a national product from Mexico. This foreign product represented a national Mexican reality, as defined by its historical setting during the revolution of 1917. The film also revolved around a commodity, food, which could be consumed in the domestic space, that is, outside any geopolitics, and thus was "safe" for North American and global mass consumption--except that, of course, gender becomes the other space through which politics is reintroduced in the domestic sphere represented by the film.

However, this "NAFTA film" was followed the same year, 1992, by another Mexican film, which also articulates a "NAFTA imagination" and is also centered on the issue of "consumption." I am referring to Cronos by Guillermo del Toro, a very successful film with the North American and global audiences and critics: it won the Critics' Week Award at Cannes and landed Del Toro a job in Hollywood with the direction of Mimic.

Cronos can be reread as the anti-NAFTA Like Water for Chocolate. In the film, magic realism and testimonio make room for a new form of gothic realism: the grandfather, an antiquarian, buys an artifact hidden in a piece of furniture, precisely the artifact that a dying industrialist, with North-American connections, wants in order to secure his health. The artifact is an alchemic object, part machine part animal, created back in the Renaissance by a Spanish alchemist who eventually had to flee to the New Word and became the Viceroy's watchmaker. This artifact, the Cronos device, turns its possessor into a vampire but, by 
the same token, makes him or her immortal. The adventures of the grandfather are witnessed by a voiceless child, the granddaughter, in what could ultimately be read as a voiceless filmic testimonio of NAFTA capitalist prey. Thus this film could also be entitled Like Blood for Chocolate, in the sense that here capitalist consumption is not centered on food but rather human beings. In this case, however, the Mexican discourse of the film abandons its national setting, as represented in Like Water for Chocolate, and resorts to a postcolonial trope--the device traveling to the New World in the Renaissance--so that its own imperialist ancestry and resulting new postcolonial position are foregrounded.

Following the cultural consumption of testimonio and magic realism across the NAFTA divide, as exemplified by Like Water for Chocolate, it seems that Latin American culture, and in this case film, is able to retell, to recontextualize the narrative of North American consumption, so that a new genre (the gothic) and a new position (the postcolonial) are deployed. In this way, Latin America escapes that very same North American consumption--be it academic or mass-culture oriented, as exemplified by Cronos. I would like to call this effect of evasion or resistance the "Like Blood for Chocolate Effect."

The above effect brings to the fore the other problem of postcolonial discourse in Latin America, which I would like to address here from a global and Atlantic standpoint. I am referring to what Alberto Moreiras defines as "historical Latinamericanism," at the core of which we would have the aura of testimonio literature ("Aura," "Global Fragments"). Beverley wonders in this respect: "Is testimonio... simply another chapter in the history of what Angel Rama called the 'lettered city' (ciudad letrada) in Latin America: the assumption, tied directly to the class interests of the creole elites and their own forms of selfauthorization, that literature and the literary intellectual are or could be adequate signifiers of the national?" (271). I agree with Beverley in his negative answer, but if we center on Latinamericanism, and more precisely in the latter's North American development, perhaps one could conclude that Latinamericanism and its institutionalization of testimonio are indeed a continuation, not of the lettered city, but the new lettered metropolis: North America reading testimonio in direct connection with the class interests of the new transnational "creole" elite. Obviously I am not a Latinamericanist, and thus I am speaking from a very local and limited location. After all, I am a Spanish Peninsularist working in North America. The specific and challenging exchange between Hernán Vidal and Nelly Richard, for example, although framed within Latinamericanism, would escape the more general approach of this article. However, from my own point of view, I want to contribute to the problematization of Latinamericanism and 
make an Atlantic and postcolonial argument for Latin America from the analysis of the "Like Blood for Chocolate effect."

Walter Mignolo is probably one of the most outspoken theorists of postcolonialism in Latin America. As he himself has declared repeatedly "It is not the historical postcolonial condition that has to attract our attention but rather postcolonialism's loci of enunciation" ("Razón" 8, my translation). He concludes that, as a result "postcolonial theoretical practices are not only changing our vision of the colonial processes, but also defying the very same basis of the Western concept of knowledge and understanding when they establish epistemological connections between geocultural site and theoretical production" ("Razón" 18, my translation). Following Ann McClintock's distinction between "settlements" and "deep settlements" ("Razón" 11), Mignolo differentiates between postmodernity and postcolonialism by ascribing them to different geopolitical areas: "postmodernity is the discourse of countermodernity that emerged from colonies of settlement [USA] whereas postcoloniality is the discourse of countermodernity manifested by colonization of deep settlement (i.e. Algiers, India, Kenya, Jamaica, Indonesia, etc." ("Razón" 11, my translation).

Although Mignolo claims that postcoloniality is changing the vision of the colonial process, he does not nevertheless locate the position of Latin America in postcoloniality. Several critics have already pointed out the chronological difficulties of applying the condition of "postcoloniality" to an area that, historically speaking, has been postcolonial since the mid nineteenth century. Mignolo argues that postcolonialism is not attractive because of its historical condition but because of its location as a "different locus of enunciation" (Razón 8). Thus the fact that even among the colonies of "deep settlement" there can be an almost 150-year gap in the process of liberation, such as in the case of Mexico and Algiers, should not be in principle a problem for postcolonial theory. However, this rather historical resilience of postcoloniality applied to Latin America points to a more important problem in the very basis of the postcolonial locus of enunciation: theory and culture seem to have the same location in Mignolo's case and thus the divide created by Latinamericanism seems to be curiously absent.

In front of the dilemma posed by the location of postcolonial theory vis-à-vis postcolonial culture, Mignolo collapses both by concluding that "postcolonial discourses and theories are constructing a postcolonial reason as locus of differential enunciation. Of course, I am oversimplifying, but I am doing so with the purpose of accentuating my perception of postcolonial reason as locus of differential 
enunciation" ("Razón" 19, my translation). In short, discourse, reason, theory, and enunciation are similarly situated as postcolonial, as belonging to a single location, regardless of their specific locus of production and enunciation across the new and global divide of knowledge production between first, second, and third worlds. I would like to argue that the reason of this collapse could be ultimately traced to what I have denominated above "reverse colonialism."

Exporting postcolonial theory to Latin America poses the following problem: the concepts of 'the West' and 'modernity' do not function as referent, geopolitical and theoretical, because of Latin America's original site of imperialism and decolonization. Spain, an empire that is in decline by the time the capitalist West develops and gives rise to French and British imperialisms, cannot be accounted for when referring to "the West, modernity, and imperialism." Mignolo clearly notes this effect when discussing language, knowledge production, and imperialism: "The Spanish language, in Latin America, was twice subaltern: it was no longer the Spanish of Spain, while at the same time, Spain and Spanish became marginal to European modernity since the seventeenth century ("Globalization" 47). Thus Mignolo accounts for the double linguistic subalternity of Latin America but, he does not apply it to the very location of Latin American postcolonial theory.

As a result, the new postcolonial condition predicated by Mignolo cannot account for the new imperialist relation between the United States, Spain, and Latin America. Unlike in the case of AngloAmerican postcoloniality, which is defined by one single axis, in the case of Latin America there are two: the old Spanish/Latin American and the new North-American/Latin American. The first axis defines the difference in terms of locus of post/colonialism but no longer represents a difference in the locus of enunciation. The second axis marks the difference in terms of post/colonialism but it also defines a difference in terms of locus of enunciation: the USA as locus of postcolonial theory of its Latin American object and Latin America as locus of postcolonial discourse and theory. The differences between locus of post/colonialism, object of postcolonial theory, and locus of postcolonial discourse cannot be erased either by turning them into a "transnational" continuum of culture:

Territories and locations are at once fixed and floating, emergent at the crossroads of places, memories, and sensibilities, where people cross borders, change languages, and deal with both the imprints of their early cultural legacies... and whatever options arise later. The transnational does not, of course, erase the national, in the sense of the place where one is born and educated (even if that place is a 
borderland), but it does imply such erasure. Nor is the transnational necessarily the postnational. It is, rather, the coexistence of regional languages, smells, tastes, objects, pictures, and so forth, with international communications, interactions, and the activities of daily life. ("Afterword" 174)

In other words, postcolonialism does open up a site of enunciation, a very important theoretical locus of enunciation in Latin America too. But if Anglo-American postcolonial theory is imported directly, the resulting place of enunciation is not located within the history of Latin American politics, culture, and theory. Both the Unites States and Spain must be accounted for in any Latin American theory of postcolonial loci of enunciation since, in the Latin American case, there are two axis of post/colonialism that cannot be reduced to a single locus. Ironically enough, postcolonialism needs to account for the uneven modernity of Latin America and thus for the latter's national development of the last 150 years. This is not simply a problem of "historicity" versus "locus;" it affects location too.

In this respect, Latin American postcolonial theory needs to become postnational first and then account for its specific location in the USA (here postnational is meant in the sense that the local political reality remains national but at the same time is directly affected by globalization). Otherwise, the lack of an explicit and clear differentiation between locus of academic enunciation and general discursive enunciation (any Latin American political and philosophical discourse) still bounces back to the formation of historical Latinamericanism. Any Latin American postcolonial theory not aware of its North American location is bound to become historical Latinamericanist discourse.

Another way to approach this problem would be to posit that Mignolo too is looking for an "epistemic testimonio," from his own North American position, whereby different philosophical and theoretical works produced in Latin America become "testimonios" of epistemic reality, politics and violence. Through the recuperation and transcription of these Latin American discourses in the United States, they become Latinamericanist discourses of Anglo-American postcolonial knowledge/power: they speak for the North American epistemic interest. As a result, Latin America and its current postcolonial condition move elsewhere, just like in the Cronos film, outside the NAFTA consumption of North American Latinamericanism. 


\section{SPANISH NEOCOLONIALISM AND THE REAL}

In front of this problem of Latin Americanism and its postcolonial discourse, allow me to elaborate the "Like Blood for Chocolate effect." There is a new stage in the globalization of Latin America that, from the epistemological and theoretical reduction effected by historical Latinamericanism, has gone overlooked so far, at least at the theoretical level. I am referring to the Spanish neocolonial, or more properly, global invasion of Latin America. Probably Telefónica, with its acquisitions in Brazil, Chile, Peru, etc. or Repsol are some of the most notable cases. However the list is long and points to the fact that, as of 1999, Spain is the second largest investor in Latin America, after the US. As Francesc Relea reports for the Spanish newspaper El País: "Entre 1990 y 1998, las empresas españolas invirtieron mas de 23.000 millones de dólares en América Latina (mas de 5,5 billones de pesetas). España es el segundo inversor en términos globales, detrás de Estados Unidos, y en algunos países ocupa la primera posición" (1).

A thorough socioeconomic research in the area remains to be done, or it is buried so deep in economic journals that the retrieval of information will resemble an archaeological expedition. However, it is clear that part of the capital of these Spanish companies is European and, more generally, global. In other words, at a moment when there is a reversed postcolonial situation at the cultural level--by which Spain is becoming Latin American--at an economic level a new form of post-postcolonial or neocolonial situation is emerging. Spain is aggressively entering Latin American markets from Chile to Cuba, so that global capital is mobilizing a history of post/coloniality (first postcolonial axis) in order to reenter this area through old channels (second postcolonial axis).

Rather than reversed postcolonialism, this seems to be a case of "lateral postcolonialism" whereby global capital, instead of entering directly through contemporary channels of imperialism, such as NAFTA, mobilizes old loci and channels of commerce to make a new incursion in those markets, under the pretense of a shared cultural and historical tradition. In other words, and unlike in the film Cronos, in reality global capitalism is finally getting hold of the Cronos device, although with a new twist: it is a Spaniard who gets it, so that he or she can then sell it to his or her European, North American, or global counterparts. In this respect Cronos is more aware of the new global and postcolonial deployment of capital than most North American postcolonial discourses of Latin America. This is the reason for the filmic inscription of the old Spanish origin in the representation the 
device (the device does not hail from a "native" or "pre-Colombian" site as the North-American Latinoamericanist discourse would desire).

If one attempts to put together the two types of postcolonialism I have isolated so far--reversed and lateral--one realizes that the global flow of capital and culture, in and out of Spain and Latin America, does not follow one single direction or channel. In other words, globalization is mobilizing older routes, such as the Hispanic Atlantic, in ways that defies national understandings of boundaries, while taking advantage of each nation and history.

My Atlantic reading of North American postcolonial theory of Latin America thus would emphasize that the colonial history of Latin America is paramount to any situated, strong version (Haraway) of postcoloniality. If Mignolo regards the specific postcolonial and historical development of Latin America since the mid nineteenthcentury as not connected with the location of postcolonial enunciation, the new Spanish neocolonialism discussed above serves as a reminder, a historical trace of the Real (Lacan, Zizek), which in its Anglo-American postcolonial unsymbolizability, becomes central to the symbolic order of actual Latinamericanist discourse.

In other academic areas, such as Hispanic lesbian, gay, and bisexual studies, queerness itself becomes part of this unsymbolizable reality of the Atlantic. Thus it is not surprise if most essay collections (Bergman and Smith, Molloy and Irwin) are in fact Atlantic in design. Furthermore, as in the case of Paul Julian Smith's Vision Machines, this Atlantic continuity is stated as the location of the Hispanic queer vis-à-vis its Anglo-American counterpart: "There may well be no way out the vision machine; certainly there is no space innocent of technology. But freed from rigid and repressive Anglo-Saxon modernity, Spanish and Cuban film and literature offer us images that speak to us eloquently even as they keep their silence" (150). Thus discourses where geopolitics are not the main concern, the postcolonial Real stops being unsymbolizable and becomes part of the symbolic order of the Hispanic Atlantic, thus proving that the latter is only a theoretical problem in geopolitical discourses of area, such as Hispanism or Latinamericanism.

If you allow me a geopolitical deployment of Lacanian theory, I would say that Latinamericanism is the imaginary discourse of Latin America and the economic and cultural relations between the USA and Latin America the symbolic-global. However, the Hispanic Atlantic would be the Real, in the sense that capital and culture hits us with the unexpected and unsymbolizable energy of an anachronistic blow, such as that of an old, and decadent imperialism like the Spanish. 
This real and yet violent decadence is nowhere better captured than in Saura's Atlantic deployment of españolada: one that aims at converting the film Tango into a global visual phenomenon, but actually brings decadence and death to Latin America as its signature. The dialogue between the aging art director--who emblematically represents Saura himself--as his new protegee--a new Argentinean Carmen of sorts--is set as the traditional male seduction ritual but, once recontextualized as Atlantic postcolonial dialogue, shows its imperialist decadent and deadly effect. The art director resorts in his discourse of seduction to colonial tropes such as the naturalized African sabhana and the Orientalist, refined, and almost-Mandarine gift.

Finally I would like to discuss the use of the term 'postnational' rather than 'transnational,' in order to refer to the new flow of globalization in the Hispanic Atlantic. Indeed my own interest resides in the fact that as a Basque critic, with my own new "area" of Peninsular studies, the only way to challenge Spanish neo-nationalism--or internal Spanish neo-imperialism--is to remap historically Spain, the "after the nationstate, yet national, Spain." I am invested in redrawing maps of Spain that do not favor globalization and its capitalist flow and, rather, function as a historical anamnesis of past imperialisms, so that the present is captured, not totalized, in its global specificity. Jameson proposes "to 'define' globalization as an untotalizable totality which intensifies binary relations between its parts--mostly nations, but also regions and groups, which, however, continue to articulate themselves on the model of 'national identities' (rather than in terms of social classes, for example" (xii). Perhaps there is a way to totalize globalization departing from specificity, not in a pro-jective way, but rather in a retro-jective or retro-spective way: globalization is the active and ahistorical actualization of history in so far as the latter can be mobilized by capital in order to further expand commodification in the present. The Hispanic Atlantic, in its global and post-national/colonial deployment, constitutes one case of such retro-jective mobilization of multinational capital.

In this case, I believe that the new incorporation of Basque immigration to Latin America and the Untied States--las Americas/Amerikak, as we call them--can serve as way to create a Basque Atlantic. This new Basque map, although truthful to its Hispanic history, can challenge and resist Spanish nationalism and, at the same time, create a discourse that will once again defy and reorganize the unidirectionality of Anglo-American theory at the same time that aligns itself with other Altantic realities such as the one outlined by Paul Gilroy in his Black Atlantic. Thus the Atlantic option is my own contribution to the important and necessary discussion of an 
impossible Meta-Hispanism that would be concerned with brokering a postnational Spain, one that becomes Latin American the moment it "plays Banderas" but bounces back into the Atlantic the moment is rendered Latin American.

\section{MAPPING THE HISPANIC AND BASQUE ATLANTIC}

Finally and in order to give a sense of my future project of mapping the Hispanic Atlantic, I would like to present two milestones, not in order to settle and draw new limits but rather to point to another geography, cartography, and enunciation.

Gertrudis Gómez de Avellaneda (1814-1873), one of the most important Hispanic writers of the Romantic period, lived most of her life in Spain where she wrote the majority of her work. She is best known for her novel Sab (1841) about a slave who sacrifices himself and his fortune (won at the lottery) in order to make her friend and mistress Carlota happy with her lover, a white empoverished landowner of English descent, Enrique. At the end, Carlota finds herself miserable in her new position as wife of a landowner and her life only regains meaning when she discovers Sab's sacrifice.

Gómez de Avellaneda has so far been excluded from the Peninsular Spanish canon although she was a colonial Spanish subject and writer. At the same time, she was first celebrated as Cuban in her return to her homeland, but then quickly rejected as nationalist sentiments grew stronger towards the end of the nineteenth century (Bravo Villasante 221). She returned to Spain in her later years. However, and since the mid 1940s, there has been a consistent attempt to incorporate her work to the Cuban and Latin American canon. Perhaps Doris Sommer's reading of her work has been the most productive and ambitious. Sommer herself acknowledges that Gómez de Avellaneda was "Neither Old World, nor New World, neither a woman's writer, nor a man's, Gertrudis was both, or something different; she was Sab" (111). Sommer is most lucid when she reads the novel as a sign of a political colonial situation that, in a psychoanalytical approach, could be best characterized as abject. The symbolic order of colonialism fails in the novel, except that Sommer herslef re- symbolize it retroactively as "Cuban:"

The result in both Sab and Memorias is an awareness that our Reality suggests its imaginary form, to borrow Lacan's terms, but that it still lacks a Symbolic expression. If reality had an expressible form, if we 
could imagine an adequate sign that would represent Sab, a sign that would name this nameless pariah in the slave-holding language of the 'parvenues' that sign might be, perhaps Cuban." (114)

What is most interesting about this retro-symbolization effected by Sommer is her attempt to re-locate Gómez de Avellaneda within the "foundational fictions" that define the rest of postcolonial Latin America, from Argentina to Mexico, throughout the nineteenth century. In other words, Sommer is resymbolizing the abject textuality of Sab as foundational and ultimately national, that is, as Cuban.

However, given the abject nature of the Avellanedan discourse, Sommer has no choice but to locate it at the beginning, in the urmoment of the later foundational narratives written by postcolonial male authors: "I am more concerned to show that she was at the vanguard of what would become the standard male canon and to suggest that the canon itself is remarkably feminized" (117). Thus colonial abjection becomes a prelude to postcolonial marriage, since in the later foundational narratives "Instead of keeping race, class, gender, and cultural differences pure, the 'historical' romances that came to be considered national novels in their respective countries married hero to heroine across those former barriers" (117). However, given the dis-phase between colonial and post-colonial narratives, Sommer wonders "The obvious question with regard to Sab is what Avellaneda's Cuba has to do with this postindependence aesthetic" (118) and she proceeds to respond by concluding that "Perhaps romance takes over because internal unity would be necessary for the fight against Spain" (118). In short, "Sab is already a projection of national consolidation" (120). Sommer is very aware that her "suggestion may be a flagrantly Menardian anachronism" (120). Thus in her Menardian reading of Cuban foundations, Sommer has to conclude that "Avellaneda must have felt safer about writing the old words in new combinations so that they would only look incoherent, because the idea of inventing new and revolutionary names evidently seemed more violent than constructive" (123). But only from a retroactive postcolonial and national reading can colonial abjection become a first step towards postcolonial violence and national construction. However, from a Hispanic Atlantic reading, one could allegorically read Sommer's own reading, á la Menard. That is, Sommer's own criticism seems "incoherent" because she feels safer writing the old (national, foundational) words in new combinations, because the idea of inventing new and revolutionary (Atlantic) names evidently seems more violent than constructive.

From a Hispanic and Atlantic position, one could read Sab not an urpostcolonial Cuban text, but rather as a colonial, Hispanic-Atlantic 
text, so that its specific historicity is rescued. In this context, and by resorting to Freud's analysis of melancholia as a device of criticism towards a lost object of desire, Sab can be read as a novel critical of colonialism, in its Atlantic melancholia. In this respect, Sab could be mobilized anew against both Latinamericanism and its foundational fictionalization as well as against Spanish global neocolonialism. Finally Sab could be a departing point to follow Sommer and effect an Atlantic reading of foundational fictions of postcolonial Latin America, so that they also become Menardian texts of the Hispanic Atlantic.

At the end of the twentieth century and in the Basque Country, the Menardian reading of an Atlantic Sab, can find its perfect counterpart. The Guggenheim Museum in Bilbao represents a postnational architecture that, although North American and postmodernist in design and history, is located in the Basque Country and has been built with Basque public capital. From a nationalist reading, this Atlantic enterprise could be contained and differentiated so that each of its aspects can be referred back and compartamentalized into a single national category: Basque, Spanish, North American. However, from a Hispanic and Atlantic reading, the Guggenheim emerges as the first sign of the weakening of a global and North American postcolonialism, in the sense that the old Spanish empire, in its specific and new Basque postnational location, is able to purchase North American art in order to embody global capitalism in culture. In other words, the Guggenheim is the reversed form of the Banderas effect.

The Hispanic Atlantic discourse and condition emerge somewhere/sometime between Gómez de Avellaneda's novel and Frank Gehry's building.

\section{Works Cited}

Arau, Alfonso. dir. Like Water for Chocolate. Arau Films International, 1992.

Balio, Tino. "'A Major Presence in all of the World's Important Markets': the Globalization of Hollywood in the 1990s." Contemporary Hollywood Cinema. Eds. Steve Neal and Murray Smith. New York: Routledge, 1998. 58-73.

Beverley, John. "The Real Thing." Gugelber 266-86.

----, José Oviedo, and Michael Aronna, eds. The Postmodernism Debate in Latin America. Durham: Duke UP, 1995. 
Bhabha, Homi. The Location of Culture. London: Routledge, 1994.

Castro-Gómez, Santiago and Eduardo Mendieta, eds. Teorías sin disciplina, Latinoamericanismo, poscolonialidad y globalización en debate. Mexico, D.F.: Porrúa; San Francisco: U of San Francisco, 1998.

Delgado, Helena. "Bajo el signo de Narciso: el discurso ensimismado de identidad nacional en el ensayo español contemporáneo." (unpublished article).

Del Toro, Guillermo, dir. $\underline{\text { Cronos. }}$ Venta Films et al., 1992.

Dirlik, Arif. "The Poscolonial Aura: Third World Criticism in the Age of Global Capitalism." Critical Inquiry 20 (1994): 328-56.

Foucault, Michel. Power/Knowledge: Selected Interviews and Other Writings, 1972-1977. Ed. and trans. Colin Gordon, et al. New York: Pantheon Books, 1980.

Gilroy, Paul. The Black Atlantic: Modernity and Double Consciousness. Cambridge: Harvard UP, 1993.

Gómez de Avellaneda, Gertrudis. Sab and Autobiography. Ed. and trans. Nina M. Scott. Austin: U of Texas P, 1993.

Gugelberg, George M., ed. The Real Thing. Testimonial Discourse and Latin America. Durham: London, 1996.

Hall, Stuart. "Cultural Studies and the Politics of Internationalization: An Interview with Stuart Hall by Kuan-Hsing Chen.". Morley, David and Kuan-Hsing Chen, eds. Stuart Hall: Critical Dialogues in Cultural Studies. New York: Routledge, 1996. 392-408.

Haraway, Donna J. "Situated Knowledges: The Science Question in Feminism and the Privilege of Partial Perspective." Simians, Cyborgs, and Women. The Reinvention of Nature. New York: Routledge, 1991. 183-201.

Jameson, Fredric. "Preface." Jameson and Miyoshi. Xi-xvii.

----. "Notes on Globalization as Philosophical Issue." 54-71.

----, and Masao Miyoshi, eds. The Cultures of Globalization. Durham: Duke UP, 1998. 
McClintock, Anne. "The Angel of Progress: Pitfalls of the Term 'Postcolonialism'." Colonial Discourse/Postcolonial Theory. Francis Barker, Peter Hulme, and Margaret Iversen, eds. Manchester: Manchester UP, 1994. 253-66.

Mignolo, Walter. "Afterword: Human Understanding and (Latin) American Interests--the Politics and Sensibilities of Geocultural Locations." Poetics Today 16:1 (Spring 1995): 171-214.

----. "Globalization, Civilization Processes, and the Relocation of Languages and Cultures." Jameson and Miyoshi. 32-53

----. "La razón postcolonial. Herencias coloniales y teorías postcoloniales." Gragoatá Niteroi 1 (1996): 7-29.

Molloy, Sylvia, and Robert McKee Irwin. Hispanisms and Homosexualities. Durham: Duke UP, 1998.

Moreiras, Alberto. "The Aura of Testimonio." Gugelberger. 192-224.

----. "Global Fragments: A Second Latinamericanism." Jameson and Miyoshi 81-102.

Nichols, Geraldine. Des/cifrar la diferencia: narrativa femenina de la España contemporánea. Madrid: Siglo Veintiuno de España Editores, 1992.

Pérez de Mendiola, Marina. Bridging the Atlantic: towards a Reassessment of Iberian and Latin American Cultural Ties. New York: State U of New York P, 1996.

Rama, Angel. The lettered city. Ed. and trans. John Charles Chasteen. Durham: Duke UP, 1996.

Relea, Francesc. "Inversiones con rechazo: America Latina se resiste a las grandes operaciones de empresas españolas." El País. May 9, 1999. Online. Lexis-Nexis, 22 Oct. 1999.

Resina, Joan Ramón. "Hispanism and its Discontents." Siglo XX/Twentieth Century 14.1-2 (1996): 85-135.

Richard, Nelli. "Reply to Vida (from Chile)." Beverley, Oviedo, and Aronna. 307-10.

Said, Edward. Culture and Imperialism. New York: Knopf, 1993. 
Saura, Carlos, dir. Tango. Beco Films, et al. 1998.

Smith, Paul Julian. Vision Machines: Cinema, Literature and sexuality in Spain and Cuba (1983-93). London: Verso, 1996.

----, and Emilie L. Bergmann, eds. ¿Entiendes? Queer Readings, Hispanic Writings. Durham: Duke UP, 1995.

Sommers, Doris. "Sab c'est moi." Genders 2 (1988): 111-26.

Spivak, Gayatri Ch. "Can the Subaltern Speak?" Marxism and the Interpretation of Culture. Cary Nelson and Lawrence Grossberg, eds. Urbana: U of Illinois P, 1991. 271-313.

----. "More on Power/Knowledge." The Spivak Reader: Selected Works of Gayatri Chakravorty Spivak. Eds. Donna Landry and Gerald MacLean. New York: Routledge, 1996. 141-74.

----. Outside in the Teaching Machine. New York: Routledge, 1993.

Vidal, Hernán. "Postmodernism, Postleftism, and Neo-Avant-Gardism: The Case of Chile's Revista de Crítica Cultural." Beverly, Oviedo, and Aronna. 282-307.

Vilarós, Teresa. El mono de la transición: una crítica cultural de la transición española (1973-93). Madrid: Siglo XXI, 1998.

Wilson, Rob, and Wimal Dissanayake, eds. Global/Local: Cultural Production and the Transnational Imaginary. Durham: Duke UP, 1996. 